\title{
Representing a divided place: the artistic-military practice of Mladen Miljanović
}

\author{
James Riding \\ University of Sheffield, UK
}

James Riding, Department of Geography, University of Sheffield, Geography and Town Planning Building, Winter Street, Sheffield S10 2TN, UK. Email: j.riding@sheffield.ac.uk

\begin{abstract}
This essay on the work of the Bosnian artist Mladen Miljanović, born in Zenica, Yugoslavia, in 1981, is wrought around an account of the divided place in which his art is mobilised. Following a short military term, Miljanović enrolled at the Academy of Arts, in Banja Luka, where he still lives. A potent opposition to a divisive ethnonationalist politics ever-present in the post-conflict, post-socialist, transition era of Bosnia-Herzegovina, Miljanović deploys what he calls an artistic-military practice. Incorporating cartographic and military surveying techniques learnt at a reserve officer military school, Miljanović deconstructs his own soldierly past and interrogates, through his artistic-military practice, an ethno-nationalist militarised Bosnia-Herzegovina. I focus in the main here on the artist's recent attempt to represent post-conflict Bosnia-Herzegovina at the 55th Biennale di Venezia, a granite triptych entitled, The Garden of Delights.
\end{abstract}

Bosnian artist Mladen Miljanović was born in Zenica, Yugoslavia, in 1981. After completing secondary school in Doboj, he attended a reserve officer military school, where he earned the rank of sergeant. As a sergeant, he trained 30 privates. Following his military term, he enrolled at the Academy of Arts in Banja Luka, where he still lives. Wrought around an account of the divided place Miljanovićs art is in and of, Bosnia-Herzegovina, here I trace a trajectory of an artist's work, which exposes the largely concealed problematic geopolitical history of this small Eastern European country during a post-conflict, post-socialist, transition era. $\frac{1}{}$ The essay opens with a description of Miljanovićs artistic-military practice, situating it as potent opposition to the ethnonationalist politics of present-day Bosnia-Herzegovina. And the essay ends in the detailing of an attempt to represent a nascent and largely undecided national imaginary of a Bosnia-Herzegovina. The artist's recent entry at the 55th Biennale di Venezia, where he exhibited a granite triptych entitled, The Garden of Delights.

It was December 1995, when the war in Bosnia was brought to an end, and the Dayton Agreement was signed in Paris. Bosnia-Herzegovina was from then on separated into two political entities: Republika Srpska and the Federation of Bosnia and Herzegovina, sometimes informally referred to as the Bosniak-Croat Federation. $\underline{\underline{2}}$ Each entity has its own government, flag, coat of arms, police force, customs, postal service, president and parliament or assembly. A 2-km zone of separation runs on either side of the inter-entity border, making a 4$\mathrm{km}$ zone in total stretching into both entities. The border is not determined by geographical features or an existing regional imaginary; rather it was created as part of the political agreement based on ethnic division, causing many people to migrate from one entity to the other or to never return home after being displaced during the war in Bosnia.

This cartographic representational idiosyncrasy enforces a nationalist overhaul of space upon individuals in Bosnia-Herzegovina. Cartography has aided a post-socialist era of never-ending transition, of brutal capitalism and diminished democracy, and the continuation of nationalist governance that it was hoped would fade away. 20 years after the end of the war in Bosnia, it is now evident - yet underreported by the 'cosmopolitan' Europeans guilty of Balkanism - that the endless post-conflict, post-socialist, transition era of BosniaHerzegovina, has meant for citizens, general impoverishment, de-industrialisation, mass unemployment, and a non-democratic rule of divisive and corrupt elites. 4 
Amidst this fractured geopolitical landscape, Bosnian artist Mladen Miljanović has produced art with the aim of deconstructing ever-present ethnic and identitarian debates in Bosnia-Herzegovina, beginning with his own perceived identity. $\frac{5}{5}$ The experience of life growing up before and during the war in Bosnia, national service training as a soldier after school and living in a divided nation since were wound up into an epigraph: / Serve Art. There is in his work and the work of other artists in the first two decades of this century, working out of Banja Luka, the de facto capital of Republika Srpska, a clear intention to be a human rights activist and an artist, enfolding art and activism to produce a form of art activism. $\underline{\underline{6}}$ This is a radical and dangerous undertaking in a society still under the heavy influence of ethno-nationalist politics in the post-conflict, post-socialist, transition era, where a reduction or flattening of identity is a part of the state rhetoric. ${ }^{?}$

Interrogating and deconstructing the ethno-nationalist history and geography of the Dayton era, Miljanovićs art is publicised and mobilised in spaces across Bosnia-Herzegovina. - His installations and performances act in-place as public disavowals of an ethno-nationalist state and a singular, pure or collective identity. Mladen Miljanović is a Bosnian-Serb. To be cast as a villainous aggressor, or a soldier of the state, is a position he staunchly rejects. His artistic-strategic response - what Miljanović calls an artistic-military practice incorporates learnt cartographic and military surveying techniques, as he occupies via site-specific performances and installations, former military bases and galleries. The artist's work reveals, in its artisticmilitary focus, a need to work through both his own past and Bosnia's past. Yet, also through this vital shared public mourning of a traumatic past he conversely aims to affect the present, for the Dayton BosniaHerzegovina created, demands, sets up and confirms ethnic division post-conflict.? Miljanović uses his past learnt military techniques to reflect and refract an ethnic division of space, and the militarisation of the state, or more specifically, the states, attempting to deconstruct and breach this division, mourning in the process, the loss of a multi-ethnic socialist Yugoslavia. When borrowing from the very cartographic techniques that created Dayton Bosnia-Herzegovina - drawing a series of lines across the country - the artist mimics the

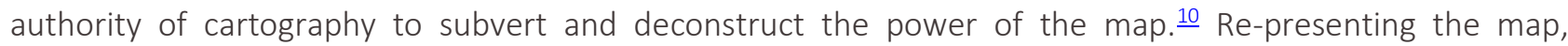
Miljanović is replicating the representational force of maps, underlining the over-mapped Dayton BosniaHerzegovina, to claim, shape and secure a new space for artists and citizens beyond the ethno-nationalist lines that divide. 11 $^{11}$

In an early series of paintings named Attack (2007) (Figure 1), Miljanović deploys this cartographic version of his artistic-military practice, simulating the mapping of a potential route towards the West. Cast as a secret operation, the artist maps lines of flight, painting on to canvas military iconography. Gaining maps of certain big European galleries, Miljanović threatens art terrororism, displaying an invasion strategy. To gain access for Bosnian artists to institutions from which they are excluded is his motive. After his art Attack, in the same year, Miljanović again depicted a military iconography, in Occupo (2007), a site-specific installation which included associated interventions in public space. Here, he targets the militarisation of society. Words frequently used in military terminology - invade, engage, occupy, captivate, attract, take, conquer, master, advance, anticipate, obviate, attempt, attack, aggress, invade, overtake, obsess, engulf - are, in this case, used in an artistic context, transformed from a military act to an artistic act. For Miljanović, the only purpose of a soldier is the occupation of space, and in his view in Occupo, the purpose of an artist is also to occupy space.

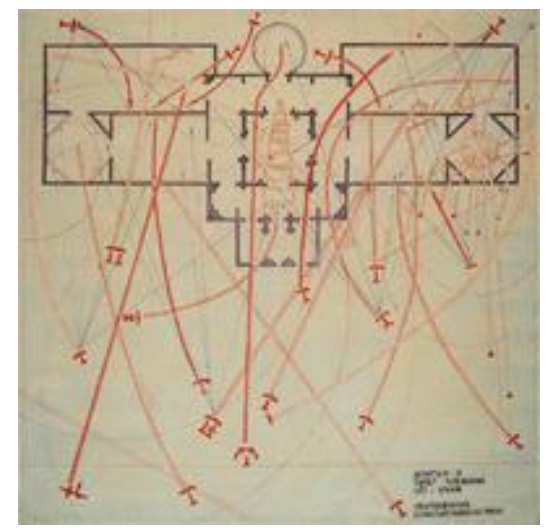




\section{Figure 1.}

Operation: Tate Modern - London 2007. Mladen Miljanović, acrylic on canvas, $150 \mathrm{~cm} \times 150 \mathrm{~cm}$. Photo courtesy of the artist.

While completing Attack and Occupo, Miljanović was working on a multidisciplinary project, which arguably takes his artistic-military practice a step further. I Serve Art (2006-2007) (Figure 2) covers several works and was produced during a voluntary isolation inside the former military base Vrbas, in Banja Luka. His isolation, as well as his site-specific performance and the production of artworks, started in October 2006. Miljanović was using art here as a way of decontaminating the space of the former military base and the broader geopolitical landscape in which it is situated. I Serve Art was, for Miljanović, a way of decontaminating his identity, a way of distancing himself from certain local art and associated institutions, which serve as a mechanism of ideological interpellation. Of I Serve Art, Miljanović writes, I found the former military base to be emblematic of the totalitarian regime apparatus which had built it, the totalitarian regime whose traumatic consequences are still present in our society. The project is about the deconstruction of that place's identity . .. A personal attitude to a similar environment already existed. I've completed the nine-month training at the military school, where I trained 30 soldiers in the last three months. I simply tried to repeat the same experience but in the context of art.

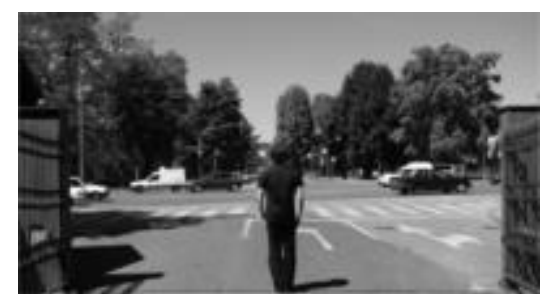

Figure 2.

I Serve Art (20 October 2006-14 July 2007). Mladen Miljanović, photo documentation of performance - day 274 (last day of performance), 14 July 2007. Photo courtesy of the artist.

Related to the traumatic consequences still present over two decades later is perhaps Miljanović's most potent image to date, a reworking of the map of Bosnia-Herzegovina. It shows the artist standing on a stool. Behind him, hanging over him, is a noose, the noose is shaped into an outline of the map of Bosnia-Herzegovina. Welcome to Bosnia (2005) is the title (Figure 3). And finally, tracing a trajectory of an artist to the present day, a mix of cartography and military iconography is once again returned to in his most recent work. Named Operation Hungary (2015), he maps a potential route to Hungary using military iconography, speaking back further to his earlier works, including Attack, Welcome to Bosnia, I Serve Art and Occupo and even further back to his former life as a soldier. Sharing similarities with a performance called At the Edge (2012), where the artist hung out of a gallery window, it speaks also to a feeling of being trapped on the edge of Europe, for Miljanović. As an artist, he needs to break out of Bosnia-Herzegovina, for the rest of Europe to take note of what has happened to this small nation since the rest of the world stopped looking. It is from this outsider position that Mladen Miljanović enters The Garden of Delights (2013). 
Figure 3.

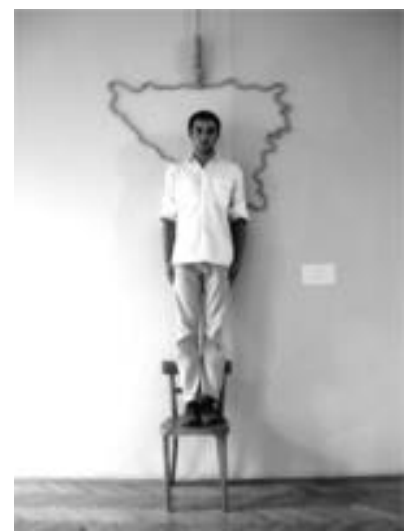

Welcome to Bosnia 2005. Mladen Miljanović, installation at Real Presence exhibition in Belgrade.

Photo courtesy of the artist.

To dream of a different reality was the task handed to Miljanović at the 55th Biennale di Venezia entitled, The Encyclopaedic Palace. The Biennale envisaged a compendium of the imaginary, unreal and uncanny, revealing a desire to go beyond the surface, the visible landscape. The Garden of Delights, a granite triptych produced to represent Bosnia-Herzegovina at the Biennale, emulates manual tombstone engraving. It was 20 years since Bosnia-Herzegovina had participated in the Biennale di Venezia, when Miljanović entered in 2013. During those 20 years, artists living in Bosnia-Herzegovina found themselves caught up in the fractured politics of the country and were as such unable to exhibit. The idea of a single artist representing a divided nation, cleaved apart in living memory, was a seeming impossibility. A Bosnia-Herzegovina pavilion at the 55th Biennale di Venezia was a rare and important attempt to represent a nascent, and largely undecided, national imaginary.

Miljanović engraved in stone a triptych of semi-mythical darkly romantic scenes of the recent past: The Garden of Delights. Originally, part of an altarpiece and so intended as a form of religious instruction, a triptych is divided into three sections, hinged together. It can be folded shut or displayed open. The middle panel is typically the largest with two smaller related works flanking it. Arising from early Christian art, it became a standard format for altar paintings from the Middle Ages onwards. Renaissance painters such as Hieronymus Bosch used the form. In Miljanović's hands, this canonic, religious, didactic form of image-making was brought to life once again as a representation of Bosnia-Herzegovina. The exaggerated gaps between each panel recall the cartographic idiosyncrasy of present-day Bosnia-Herzegovina cleaved apart in living memory: a triptych of Croat, Serb and Bosniak. While Miljanović's use of a Christian form of image-making, to represent a BosniaHerzegovina, remembers the divisive part that religion played during the war in Bosnia.

The images that adorn the triptych elevate a form of naive, kitsch art making. Like Hieronymus Bosch's triptych The Garden of Earthly Delights, Miljanović's images are not earthly they are otherworldly. They inscribe for eternity an agricultural past, a folk bygone culture, which is slowly disappearing. The very act of engraving something in stone lends the images permanence, mimicking the work of stone masons chipping away names and dates, in the service of memory and posterity. As such, a yearning to memorialise is evident, an obligation to bear witness, to the dead as well as the living, creating a tombstone for a rural, pastoral, feudal BosniaHerzegovina. Yet, what remains, and marks these slabs of stone, is a deep ambivalence to the very idea of image-making, interrogating the privileged relation to truth images have. $\underline{12}$ Using the religious triptych, an anachronistic form of image-making, Miljanović denounces all the common images we have of BosniaHerzegovina and the Balkans more widely, as an inherently violent place.

This act echoes the well-established literature on representations of the Balkans in literary studies and geography. $\underline{\underline{13}}$ In this work, it is argued that representations of the Balkans, loaded the Balkans with negative connotations: inharmonious conditions, small antagonistic states, hostile nationalities, all of which conspired to form the intractable Balkan or Eastern question. ${ }^{14}$ Slavoj Žižek wrote of the Balkans as Europe's ghost, down there, always somewhere a little further to the southeast, a photographic negative of tolerant, multicultural, post-political, post-ideological Europe. $\frac{15}{} \mathrm{~A}$ 'postmodern racism' exists, Žižek argues, where the Balkans are 
seen as the intolerant other, while the rest of Europe has supposedly come to terms with otherness in its much vaunted - indeed marketed - language of cosmopolitanism and multiculturalism. $\frac{16}{}$ Referring to this continuing Balkanism, the British journalist Misha Glenny opens his magnum opus, The Balkans, 1804-1999, with a description of Bram Stoker's Dracula, as the Balkans it seems, still occupy the centre of some sort of dystopian imaginative whirlpool. $\underline{\underline{17}}$

Each image of a person, animal or object engraved onto the otherworldly landscape of The Garden of Delights (Figure 4) was found and collected. They are tombstone motifs and can be traced to specific towns, villages and cities across Bosnia-Herzegovina, the vast majority in Republika Srpska. These are illustrations of human life in stone, odd, kitsch images of personal indulgence, sentimental, garish and perhaps in poor taste. They are appreciated for this reason, by the artist Miljanović. For as Gaston Bachelard writes, the communicability of an unusual image is a fact of great ontological significance. $\underline{18}$ The graveyard as seen by Miljanović stores an encyclopaedia of unusual images of great ontological significance. Their peculiarity, when placed on to a triptych is revealed, yet each and every one of them represents a life, in a particular geographical location. Those who reside in the grave wish to be remembered in a certain way. As such, Miljanović sees a graveyard as storing an encyclopaedia of images of individual lives, where single images become a collective societal expression.

\section{Figure 4.}

The Garden of Delights (2013). Mladen Miljanović, installation, engraved drawing on granite, 55th Venice Biennale, 2013. Photograph: Drago Vejnović. Photo courtesy of the artist.

The large central panel of The Garden of Delights (Figure 5) is a square filled with more than 100 tombstone motifs of people, animals and objects found and collected across Bosnia-Herzegovina. The location of people, animals and objects maps directly onto the famous Renaissance triptych, Bosch's The Garden of Earthly Delights, which provides the foundation of this work. Each image engraved on to the black granite triptych The Garden of Delights was collected through a process of exploring graveyards across Bosnia-Herzegovina, documenting the gravestones in much the same way an anthropologist works. The tombstone motifs, redepicted in the triptych give over a snapshot of a particular culture. Used most prevalently in the predominantly Orthodox, Bosnian-Serb region of Bosnia-Herzegovina, Republika Srpska, they disclose the personal indulgencies and lifestyles of people. A kitsch imagery, they are unique to this region. Although some of the tombstone motifs are objects that the person held dear, a symbolic gesture towards an afterlife, or a political, or national affiliation, many are portraits of the person in the grave, self-portraits. The very faces of the dead look out of the grave, beyond the grave. These hyperrealistic tombstone motifs are head stones, little biographies of a person. 


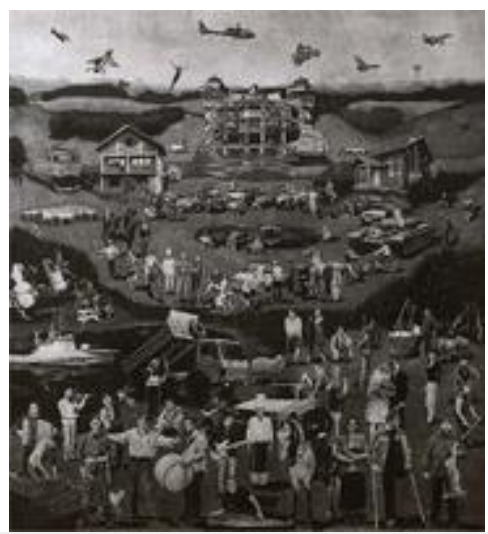

Figure 5.

The Garden of Delights (2013). Mladen Miljanović, installation, engraved drawing on granite, 55th Venice Biennale, 2013. Photograph: Drago Vejnović. Photo courtesy of the artist.

Wandering through a graveyard causes a certain way of travelling, seeing and remembering. $\frac{19}{\text { You walk lines, }}$ look down at the stones and away from the landscape in which they are placed, remembering people and bringing their lives back into presence. A building-up-to presence occurs, where objects of memory, gravestones, work in landscape as palpable, haunting presences: the very materiality of memory. ${ }^{20}$ Avenues of names and dates, and the people who lived and died near the graveyard, are laid out, their histories ready at hand to be summoned from the earth. This mode of walking occurred when I was searching for a tank graveyard near Doboj, north Republika Srpska. There I stumbled across the type of tombstones Miljanović depicted in his triptych. Some were placed together in a graveyard just off the road, where they act as the symbolic centre of this traumatised landscape. $\underline{21}$ I see once in the graveyard, a single tombstone. It is engraved with a motif, a tank. The person, to whom the stone refers, wished to be remembered as a fighter, a contributor to the building of the entity, partially recognised state, or nation, Republika Srpska.

The kitsch, random, nostalgic and twee tombstone motifs, I could see around the graveyard, are unique to this place. They exist as art or artefact as well as utilitarian grave-marker, saying something about the buried individual, transcending the fundamentally unchanging, functional aspect of the gravestone. They are a folk art drawn upon in death, an expression of art that people are using as a form of remembrance, an art to be remembered by. Tombstones and their motifs are moments in time and place, symbolic of death, with a deeply anthropological value. The stones in the graveyard near Doboj, in north Republika Srpska, are no different. They are distinctly regional, symptomatic of a region. Their emergence could be seen as a material manifestation of Republika Srpska.

Yet, these peculiar tombstone motifs are representative of a turbo-folk culture; they perform the past strangely and in some cases, arguably divisively. Turbo-folk as a form of popular culture is controversial in the new states of the former Yugoslavia, described as backward and misogynist, evoking Serb nationalist iconography and representing a threat to cosmopolitanism. $\underline{22}$ A form of resistance to the threat of neoliberalism, turbo-folk remembers a traditional rural past, where people and land had some form of deep spiritual connection. Emerging out of a distrust of the wider new European project post-1989, turbo-folk is more than a musical genre; it is a lifestyle choice, with very specific political, cultural and historical underpinnings. The appearance of turbo-folk coincided with the rise of nationalism in Balkan socialist states. It would go on to serve as a soundtrack to a brutal ethnic conflict and was arguably fundamental to the processes of cultural, political and social change in Yugoslavia. $\underline{23}$

Borrowing these peculiar tombstone motifs to represent Bosnia-Herzegovina at the 55th Biennale di Venezia is a reference to the prevalence of a turbo-folk ethno-nationalist culture in the post-socialist transition era. In doing so, Mladen Miljanović remembering his own past as a tombstone engraver collects these kitsch turbofolk images, as an anthropologist might, placing them together as if in a graveyard. His act of engraving is a subversion of remembering the past. Using a didactic and nowadays seemingly absurd form of art on which to place the images, the triptych, interrogates the politics of remembering the past in post-conflict Bosnia- 
Herzegovina. Sites of commemoration, cemeteries and monuments present in the landscape often remember only a single ethnic group, reinforcing the geopolitical categories that the murderers imposed on their victims. People are remembered as Bosnian-Serb, Bosnian-Croat or Bosniak as Orthodox, Catholic or Muslim. Not as fathers, mothers, daughters or sons. There are few common sites of commemoration or collective spaces to remember the victims of war. What is more, remembering has become a political statement, as those mourning are categorised and enfolded within persistent ethnic and identitarian narratives. $\underline{24}$ The task for Mladen Miljanović in attempting to represent a Bosnia-Herzegovina is always to travel outside of and beyond these 'ever-present geopolitical discourses' and to somehow craft, engrave, but not entomb, an identity of his own. $\frac{25}{}$

\section{Acknowledgments}

The author would like to thank Dr Jessica Dubow for reading the article prior to submission, the artist Mladen Miljanović for permitting the use of his artwork and the Leverhulme Trust for funding the wider project on which this article is based.

\section{Funding}

This research was supported by the Leverhulme Trust: Leverhulme Early Career Research Fellowship, New Regional Geographies (For Sarajevo).

\section{Notes}

1 1. See S.Horvat and I.Štiks (eds), Welcome to the Desert of Post-Socialism: Radical Politics after Yugoslavia (London: Verso, 2015).

«2. See D.Campbell, National Deconstruction: Violence, Identity, and Justice in Bosnia (Minneapolis: University of Minnesota Press, 1998); M.Glenny, The Fall of Yugoslavia (London: Penguin, 1992); A. Little and L.Silber, The Death of Yugoslavia (London: Penguin, 1996); D.Rieff, Slaughterhouse: Bosnia and the Failure of the West (London: Vintage Random House, 1995); M.Thompson, A Paper House: The Ending of Yugoslavia (London: Vintage, 1992); G.Toal and C.Dahlman, Bosnia Remade: Ethnic Cleansing and its Reversal (Oxford: Oxford University Press, 2011); A.Jeffrey, The Improvised State: Sovereignty, Performance and Agency in Dayton Bosnia (London: Wiley Blackwell, 2012).

«3. See Horvat and Štiks, Welcome to the Desert of Post-Socialism.

$₫ 4$. See for a clarification of what is meant by 'cosmopolitan' Europeans, J-L.Nancy, Being Singular Plural (Stanford: Stanford University Press, 2000); see the following texts for a description of Balkanism, F.W.Carter (ed.), An Historical Geography of the Balkans (London: Academic, 1977); M.Glenny, The Balkans 1804-1999: Nationalism, War and the Great Powers (London: Granta, 1999); V.Goldsworthy, Inventing Ruritania: The Imperialism of the Imagination (London: Yale University Press, 1998); M.Todorova, Imagining the Balkans (Oxford: Oxford University Press, 1997); S.Žižek, The Fragile Absolute: Or Why Is the Christian Legacy Worth Fighting for? (London: Verso, 2000); M.Mazower, The Balkans: From the End of Byzantium to the Present Day (London: Phoenix, 2002); see for a description of post-democratic governance post-conflict in Bosnia-Herzegovina, D.Arsenijević, 'Mobilising Unbribable Life', in A.Mousley (ed.), Towards a New Literary Humanism (Basingstoke: Palgrave Macmillan, 2011), pp. 166-81.

«5. See Campbell, National Deconstruction.

«6. See in particular the work of Miljanović's mentor, Veso Šovilj, and his 2013 return exhibition, And What do you Represent?

«7. See Horvat and Štiks, Welcome to the Desert of Post-Socialism.

«8. See for a full account of what is meant by Dayton Bosnia-Herzegovina, Jeffrey, The Improvised State. $₫$. See Jeffrey, The Improvised State. 
«10. See J.B.Harley, 'Deconstructing the Map', Cartographica, 26(2), 1989, 1-20; also D.Wood, The Power of Maps (New York: The Guildford Press, 1992).

$₫ 11$. See Arsenijević, 'Mobilising Unbribable Life'; also Horvat and Štiks, Welcome to the Desert of PostSocialism.

⒓ See J-L.Nancy, The Ground of the Image (New York: Fordham University Press, 2005).

$₫ 13$. See Goldsworthy, Inventing Ruritania; also Todorova, Imagining the Balkans.

«14. See Carter, An historical geography of the Balkans; also Mazower, The Balkans.

$₫ 15$. Žižek, The Fragile Absolute, pp. 1-2.

⒗ Žižek, The Fragile Absolute, pp. 1-2.

«17. Glenny, The Balkans 1804-1999; B.Stoker, Dracula (Edinburgh: Constable \& Co., 1897).

«18. G.Bachelard, The Poetics of Space (London: Orion Press, 1964).

ي19. See J.Riding, 'Death Drive: Final Tracings', in H.Hawkins and E.Straughan (eds), Geographical Aesthetics: Imagining Space, Staging Encounters (Farnham: Ashgate, 2015), pp. 181-96.

«20. J.Wylie, 'Landscape, Absence, and the Geographies of Love', Transactions of the Institute of British Geographers, 34(3), 2009, pp. 275-89; see also A.Maddrell, 'Living with the Deceased: Absence, Presence and Absence-Presence', Cultural Geographies, 20(4), 2013, pp. 501-22.

«21. See A.Maddrell and J.D.Sidaway (eds), Deathscapes: Spaces for Death, Dying, Mourning and Remembrance (Farnham: Ashgate, 2010).

$₫ 22$. See U.Cvoro, Turbo-Folk Music and Cultural Representations of National Identity in Former Yugoslavia (Farnham: Ashgate, 2014).

«23. See Cvoro, Turbo-Folk Music and Cultural Representations of National Identity in Former Yugoslavia.

«24. J.Riding, 'Landscape, Memory, and the Shifting Regional Geographies of Northwest BosniaHerzegovina', GeoHumanities, 1(2), 2015, pp. 378-97.

«25. Campbell, National Deconstruction, p. 15.

\section{Author biography}

James Riding is a Leverhulme Early Career Research Fellow in the Department of Geography at the University of Sheffield, leading the project New Regional Geographies (For Sarajevo). 